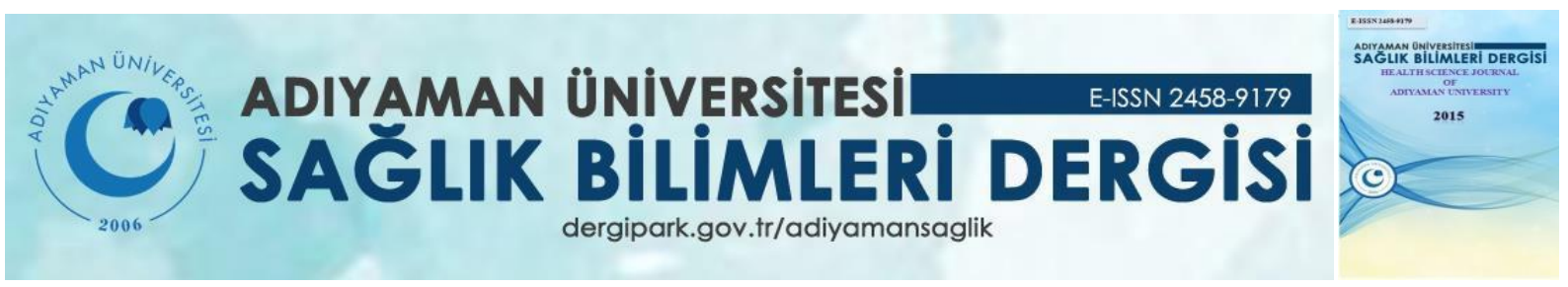

Araştırma/Research

The Importance Of Nasofrontal Angle In Recurrent Childhood Idiopathic Epistaxis

\author{
İbrahim Hakan BUCAK ${ }^{1}$, Mehmet KARATAŞ ${ }^{2}$, Habip ALMIŞ³, \\ Sedat DOĞAN ${ }^{4}$, Mehmet TURGUT ${ }^{5}$ \\ ${ }^{1,3,5}$ Department of Pediatrics, Adiyaman University, Adiyaman, Turkey \\ ${ }^{2,4}$ Department of Ear-Nose-Throat, Adiyaman University, Adiyaman, Turkey
}

$\begin{array}{ll}\text { ORCID }^{1}: 0000-0002-3074-6327 & \text { ORCID }^{4}: 0000-0002-7569-8509 \\ \text { ORCID }^{2} \text { : 0000-0001-8974-3414 } & \text { ORCID }^{5}: 0000-0002-2155-8113\end{array}$

ORCID $^{3}$ : 0000-0001-9327-4876

\begin{abstract}
Aim: Epistaxis is a common, usually self-limiting, clinical condition in childhood. Many factors have been identified in the etiology of epistaxis although one third of epistaxis called idiopathic. Anatomical structure of nose should be taken into account in the evaluation of patients with recurrent idiopathic epistaxis. Aim of this study to reveal whether or not there is any correlation between nasofrontal angle and recurrent idiopathic epistaxis in children.
\end{abstract}

Methods: The patients referred to the pediatric and ear-nose-throat outpatient clinics for recurrent epistaxis between October 2014-April 2015 were enrolled in the study and accepted as study group. The control group was chosen from patients without epistaxis. The NFA was measured with a commercial angle meter under normal anatomic position by the same researcher.

Results: Sixty-two subjects with recurrent idiopathic epistaxis and ninety subjects without epistaxis were enrolled in this study and named as the study group and the control group, respectively. The mean NFA of the study group was $139.29 \pm 6(125-159)^{\circ}$ while the mean NFA of the control group was 133.8 $\pm 4.8(123-146)^{\circ}$. The NFA in the study group was significantly higher than that in the control group $(\mathrm{p}<0.001)$.

Conclusion: Increased NFA can be accepted as one of the abnormalities in the anatomical structure of the nose in the etiologic classification of epistaxis. More researches will be needed to identify the importance of NFA for recurrent idiopathic epistaxis.

Key words: epistaxis, children, nasofrontal angle

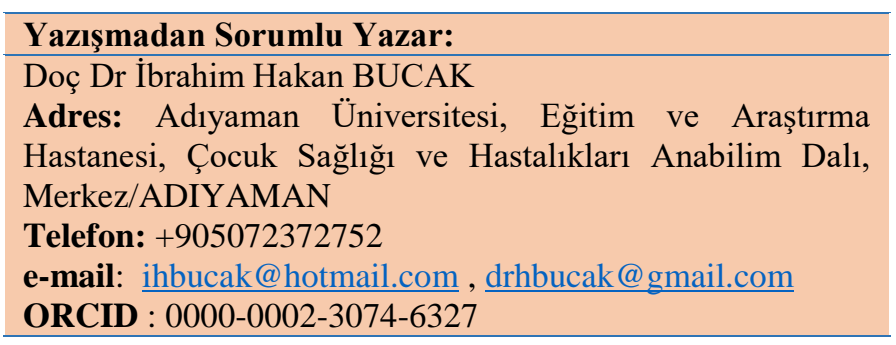

Doi: 10.30569.adiyamansaglik.638799

Geliş Tarihi : 27.10.2019

Kabul Tarihi : 10.12.2019

Atıf Gösterimi/How to Cite: Bucak İH, Karataş M, Almış H, Doğan S, Turgut M. The Importance Of Nasofrontal Angle In Recurrent Childhood Idiopathic Epistaxis. Adıyaman Üni. Sağlık Bilimleri Derg. 2019; 5(3);1788-1795. doi:10.30569.adiyamansaglik.638799 


\section{Çocukluk Dönemi Tekrarlayan İdiopatik Epistaksiste Nazofrontal Açının Önemi}

\section{ÖZ}

Amaç: Epistaksis çocukluk çağında yaygın, genellikle kendi kendini sınırlayan klinik bir durumdur. Epistaksis etyolojisinde birçok faktör kanıtlanmış olsa da, üçte biri idiopatik olarak değerlendirilmektedir. Tekrarlayan idiopatik epistaksis vakalarının değerlendirilmesinde anatomik yapı dikkate alınmalıdır. Bu çalışmanın amacı, çocuklarda nazofrontal açı (NFA) ile tekrarlayan idiyopatik epistaksis arasında bir ilişki olup olmadığını ortaya koymaktır.

Yöntem: Ekim 2014-Nisan 2015 tarihleri arasında tekrarlayan epistaksis nedeniyle pediatrik ve kulak burun boğaz polikliniğine başvuran hastalar çalışmaya alındı ve çalışma grubu olarak kabul edildi. Kontrol grubu, burun kanaması olmayan hastalardan seçildi. NFA, aynı araştırmacı tarafından normal anatomik pozisyonda ticari bir açı ölçer ile ölçülmüştür.

Bulgular: Tekrarlayan idiyopatik epistaksisi olan altmış iki olgu ve epistaksisi olmayan doksan olgu çalışmaya alındı ve sırasıyla çalışma grubu ve kontrol grubu olarak adlandırıldı. Çalışma grubunun ortalama NFA değeri 139,29 \pm 6 (125-159) ${ }^{\circ}$ iken, kontrol grubunun ortalama NFA değeri 133,8 $\pm 4,8$ (123-146) ${ }^{\circ}$ idi. NFA, çalışma grubunda kontrol grubundan anlamlı olarak yüksekti $(\mathrm{p}<0.001)$.

Sonuç: NFA'nın artışı epistaksis etyolojisi sınıflamasında burnun anatomik yapı bozukluklarından biri olarak kabul edilebilir. NFA'nın tekrarlayan idiyopatik epistaksis için önemini belirlemek için daha fazla araştırmaya ihtiyaç duyulmaktadır.

Anahtar Kelimeler: Epistaksis,Çocuk,Nazofrontal Açı

\section{BACKGROUND}

Bleeding from the nose and nasal cavity is called epistaxis. It is a common and usually selflimiting clinical condition in childhood $(1,2)$. The incidence of epistaxis is approximately $60 \%$ in all age groups, and emergent inervention was required for $6 \%$ of these patients $(3,4)$. Epistaxis is classified as either anterior or posterior according to anatomical site. More than 90 $\%$ of episodes of epistaxis occur at the anterior part of the nasal septum (5). There are local and systemic causes of epistaxis. Nasal anatomical pathologies like septal deviation, intranasal polyps, adenoid hypertrophy, vascular malformation, or telangiectasia, are known to predispose epistaxis $(1,6,7)$. Repeated nasal bleeding with no spesific cause is defined as recurrent idiopathic epistaxis (RIE) $(8,9)$. 
The nasal bone starts to develop in the sixth week of gestation and evaluation of nasal bone in second trimester is used for detection of chromosomal anomalies in utero $(10,11)$. Nasofacial maturation is ended approximately at 16 years in both sexes (12). Nasofrontal angle (NFA) was formed by two lines; one line tangential to the glabella through the nasion that intersects the other one drawn tangential to nasal dorsum (13). NFA can affect the shape of the nose and midfacial length in profile view. It is a guide for reconstructive nasal surgery and early detection of congenital abnormalities in utero. Some syndromes have been suspected with abnormal nose structure, like depressed nasal root, for many pediatricians (14).

Anatomical structure of nose should be taken into account in the evaluation of patients with recurrent idiopathic epistaxis. At this point NFA may help to explain the etiology of idiopathic epistaxis. In this study, we investigate the importance of the NFA in children with RIE for the first time in literature.

\section{METHODS}

This study was designed as prospective. The patients referred to the pediatric and ENT outpatient clinics for recurrent epistaxis between October 2014-April 2015 were enrolled in the study and accepted as study group. They underwent detailed ENT examination including anterior rhinoscopy, nasal endoscopy, and nasopharyngeal x-ray for adenoid hypertrophy and pediatric physical examination as well as complete blood counts and bleeding tests. RIE was accepted as two or more epistaxis in different times with uncertain etiology. The control group was chosen from patients without epistaxis. The measurement of NFA were calculated in degrees $\left({ }^{\circ}\right)$. The NFA was measured with a commercial angle meter under normal anatomic position by the same researcher. Epistaxis site (anterior and/or posterior), age, and gender were recorded for each patient.

Patients with bleeding diathesis, thrombocytopenia, topical corticosteroid usage, hypertension, acute/chronic sinusitis, septal deviation, adenoid hypertrophy, vascular malformation, nose picking, and any diseases that cause epistaxis were questioned and they were excluded the study.

Approval for the study was guaranted by the local ethics committee (approval no: 2014/08-3). Written informed consent was collected from parents before the study began.

The Statistical Package for the Social Sciences version 16 for Windows (Chicago, IL, U.S.) software was used for statistical analysis. Gender was assessed with the Chi-square method. 
Age and NFA were assessed with the Mann-Whitney U test. Results were considered significant at the $\mathrm{p}<0.05$ level.

\section{RESULTS}

Seventy-six patients with recurrent epistaxis who were admitted to our hospital between October 2014 and April 2015 were enrolled in this study. One patient with bleeding diathesis, one patient with thrombocytopenia, three patients with chronic sinusitis and adenoid hypertrophy, four patients with septal deviation, and five patients with nose picking were excluded from the study. The study group and the control group consisted of 62 (32 males, 30 females) and 90 (54 males, 36 females) participants, respectively. The mean age for study group and control group were $100.9 \pm 46.84$ (41-214) and $89 \pm 38.1$ (41-181) months, respectively. The study group and control group male/female ratios were 1.06 and 1.5 , respectively. There was no statistically significant difference between the groups with respect to age $(p=0.147)$ and gender $(\mathrm{p}=0.305)$. In the study group, anterior epistaxis, posterior epistaxis and anterior/posterior epistaxis patient number were $55(88.7 \%), 5(8.1 \%)$, and $2(3.2 \%)$, respectively.

The mean NFA of the RIE group and the control group were $139.6 \pm 7(125-159)^{\circ}$ and 133.84 \pm 4.8 (123-146) ${ }^{\circ}$, respectively. The NFA in the RIE group was statistically significantly higher than that in the control group ( $\mathrm{p}<0.001$ ). The NFA difference between the groups is shown in Figure 1.

Figure 1. The mean NFAs of RIE group and control group are depicted as red and blue lines, respectively. 


\section{DISCUSSION}

The nose has a rich blood vessels so epistaxis may occure easily with spontenaously or local travma or secondary to a systemic disease (15). The incidence of epistaxis is approximately 60 $\%$ in all age groups (3). With the same direction, epistaxis is a common admission complaint to ENT and pediatric outpatient clinics or emergency department at childhood. Epistaxis in children is not usually life-threatening, however it is irritating for parents.

The prevalence of epistaxis in children increased in 3-8 years of age (9). In the present study, we found the mean age of RIE group was $100.9 \pm 46.8$ months. In literature, epistaxis is more frequently seen in males than females (4). In this study, the RIE group male/female ratio were 1.06. Based on the site of origin, epistaxis is classified as either anterior or posterior. In children and young adults, anterior epistaxis is more common than posterior. In this study, anterior epistaxis accounts for approximately $88 \%$ of episodes of epistaxis. Age distribution, male/female ratio and epistaxis site were similar to previous studies.

Nose picking, acute/chronic sinusitis and irritants (e.g., cigarette smoke), leukemia and liver disease, intranasal neoplasm (especially elderly patients), bleeding disorders (such as hemophilia, platelet dysfunction, etc.), thrombocytopenia (due to immune welded), hypertension (usually in the adult population), seasonality (higher incidence in winter), foreign bodies, rhinitis, medications (anticoagulants, topical corticosteroids, etc.) and trauma can cause to epistaxis $(1,6,16-23)$.

Naturally, anatomical abnormalities can cause recurrent epistaxis with known etiology such as septal deviation and vascular malformation $(6,24)$. Although adenoid hypertrophy was not emphasized as a common cause of epistaxis in the literature, Wahab et al reported its incidence as $4 \%$ in children with recurrent epistaxis (7). Adenoid hypertrophy, as an obstructive nasal pathology, has a negative effect on nasal air flow anterior to nasopharynx which causes drying of nasal mucosa with resultant mucosal disruption and epistaxis. Liu et al. demonstrated that septal deviation causes asymmetry in airflow through the nasal passages (25). Chen et al have proven that nasal bone fracture has negative effects on nasal airflow (26). Bailie et al. evidenced that wall shear stress (a friction force resulting from nasal airflow and an important tool in the air conditioning ability of the nasal cavity) is concentrated within Little's region (the anterior region of the nasal septum and it has a rich capillary supply) which explains the predilection of spontaneous nosebleeds at this region (27). 
Idiopathic epistaxis is termed that nasal bleeding for which no specific cause is identified (9). Many factors have been identified as above in the etiology of epistaxis although one third of epistaxis called idiopathic. RIE prevalance is vary between 8-40\% (9). Beside the length of the nose and the columella, the nasofrontal angle, the rhinion, the supratip region, the tip and the columella-labial junction, NFA is one of the most important anatomic landmark of the nose for surgeons dealing with facial aesthetic surgery (28). In literature, there are two studies related with NFA showing that mean NFA of healthy young Turkish males and girls were $134.9 \pm 7.7^{\circ}$ and $133.6 \pm 8.8^{\circ}$, respectively $(29,30)$. An aesthetically nasofrontal angle is determined as within the range of $130^{\circ}$ in males and $134^{\circ}$ in females (31). This results are similar to our control group and support the our findings.

The main supply of nasal cavity is from anterior ethmoid artery (AEA) and posterior ethmoid artery (PEA) which are the branches of ophthalmic artery. AEA reaches to nasal cavity via anterior ethmoid canal, crosses the anterior skull base and ethmoid roof and supplies anterior superior part of the septum. PEA passes through posterior ethmoid canal, its route to anterior cranial fossa, and then supply the superior part of posterior nasal septum (32). Monjas-Canovas et al. has studied radiological anatomy of ethmoidal arteries on 20 cadavers heads with computerized tomography imaging and suggested several measurements among arteries, skull base, nasal spine, optic nerve (33). They found AEA in 95\% (38/40) of cases and it originated from the ophthalmic artery in $87.5 \%$ (34/40) of nasal cavities. In 6 cases, normal variants were seen. Only in 14/40 cases, PEA was localised, with $28.5 \%$ (4/14) of them showing normal variants. The distance between the nasion and the anterior ethmoidal canal was $29.31 \pm 2.53$ $\mathrm{mm}$, the distance was $11.24 \pm 2.14 \mathrm{~mm}$ from AEA to PEA and from PEA to the optic nerve, $7.26 \pm 1.33 \mathrm{~mm}$. In the light of these varying localisation of the vascular structures, a wide or narrow NFA may affect the distances among nasion, AEA, and PEA. Abnormal course of these vessels may play a predisposing factor in the etiology of RIE (34).

This study revealed that NFA in the RIE group was statistically significantly higher than that of the control group $(\mathrm{p}<0.001)$. We compared, for the first time in literature, the NFA in patients with RIE and patients without epistaxis. This study showed that increased NFA is a possible geometric risk factor for RIE. 


\section{CONCLUSIONS}

In the coming years, NFA measurement may have a function in the future which serve as a geometrical tool in the evaluation of pediatric patients with epistaxis after further supportive studies. More researches will be needed to identify the importance of NFA for RIE.

\section{ACKNOWLEDGEMENTS}

We are grateful to Ayse Bayram and Esra Bucak for support with the Figure 1.

\section{REFERENCES}

1. Haddad Jr J. Epistaxis. In: Kleigman RM, Stanton BF, St Geme JW, Schor NF, Behrman RE, editors. Nelson Textbook of Pediatrics. Philadelphia: Elsevier Saunders Inc; 2011:1432-3.

2. Bjelakovic B, Bojanovic M, Lukic S, Saranac L, Vukomanovic V, Prijic S, Zivkovic N, Randjelovic D.. The therapeutic efficacy of propranolol in children with recurrent primary epistaxis. Drug Des Devel Ther. 2013;7:127-9.

3. Ahmed AE, Abo El-Magd EA, Hasan GM, El-Asheer OM. A comparative study of propranolol versus silver nitrate cautery in the treatment of recurrent primary epistaxis in children. Adolesc. Health Med Ther. 2015;6:165-70.

4. Varshney S, Saxena RK. Epistaxis: A retrospective clinical study. Indian J Otolaryngol Head Neck Surg. 2005;57(2):125-9.

5. Yau S. An update on epistaxis. Aust Fam Physician. 2015;44(9):653-6.

6. Kodiya AM, Labaran AS, Musa E, Mohammed GM, Ahmad BM. Epistaxis in Kaduna, Nigeria: a review of 101 cases. Afr Health Sci. 2012;12(4):479-82.

7. Wahab M S A, Fathy H, Ismail R, Mahmoud N. Recurrent epistaxis in children: When should we suspect coagulopathy?. The Egyptian Journal of Otolaryngology. 2014;30(2):106-11.

8. Kucik CJ, Clenney T. Management of epistaxis. Am Fam Physician. 2005;71:305-11.

9. Qureishi A, Burton MJ. Interventions for recurrent idiopathic epistaxis (nosebleeds) in children. Cochrane Database Syst Rev. 2012;9:CD004461.

10. Oztürk H, Ipek A, Tan S, Yener Öztürk S, Keskin S, Kurt A, Arslan H. Evaluation of fetal nasofrontal angle in the second trimester in normal pregnancies. J Clin Ultrasound. 2011;39:18-20.

11. Cicero S, Curcio P, Papageorghiou A, Sonek J, Nicolaides K. Absence of nasal bone in fetuses with trisomy 21 at 11-14 weeks of gestation: an observational study. Lancet. 2001;358(9294):1665-7.

12. Van der Heijden P, Korsten-Meijer AG, van der Laan BF, Wit HP, Goorhuis-Brouwer SM. Nasal growth and maturation age in adolescents: a systematic review. Arch Otolaryngol Head Neck Surg. 2008;134:1288-93.

13. Song KJ, Lee EJ, Lee JM, Jo GH, Kim KS. The effect of caudal septoplasty on nasal angle parameters: a report on 69 cases. Clin Otolaryngol. 2016;41:185-9.

14. Adams DJ, Clark DA. Common genetic and epigenetic syndromes. Pediatr Clin North Am. 2015;62:41126.

15. Bernius M, Perlin D. Pediatric ear, nose, and throat emergencies. Pediatr Clin North Am. 2006;53:195214. 
16. Sandoval C, Dong S, Visintainer P, Ozkaynak MF, Jayabose S. Clinical and laboratory features of 178 children with recurrent epistaxis. J Pediatr Hematol Oncol. 2002;24:47-9.

17. Zhou F, Xu Y, Zhang Z, Wu X, Jin R. Severe Hemorrhage in Chinese Children With Immune Thrombocytopenia. J Pediatr Hematol Oncol. 2015;37:e158-61.

18. Kikidis D, Tsioufis K, Papanikolaou V, Zerva K, Hantzakos A. Is epistaxis associated with arterial hypertension? A systematic review of the literature. Eur Arch Otorhinolaryngol. 2014;271:237-43.

19. Comelli I, Vincenti V, Benatti M, Macri GF, Comelli D, Lippi G, Cervellin G. Influence of air temperature variations on incidence of epistaxis. Am J Rhinol Allergy. 2015;29:e175-81.

20. Abou-Elfadl M, Horra A, Abada RL, Mahtar M, Roubal M, Kadiri F. Nasal foreign bodies: Results of a study of 260 cases. Eur Ann Otorhinolaryngol Head Neck Dis. 2015;132:343-6.

21. Murray AB, Milner RA. Allergic rhinitis and recurrent epistaxis in children. Ann Allergy Asthma Immunol. 1995;74:30-3.

22. Petty DA, Blaiss MS. Intranasal corticosteroids topical characteristics: side effects, formulation, and volume. Am J Rhinol Allergy. 2013;27:510-3.

23. Daniel M, Raghavan U. Relation between epistaxis, external nasal deformity, and septal deviation following nasal trauma. Emerg Med J. 2005;22:778-9.

24. O'Reilly BJ, Simpson DC, Dharmeratnam R. Recurrent epistaxis and nasal septal deviation in young adults. Clin Otolaryngol Allied Sci. 1996;21:12-4.

25. Liu T, Han D, Wang J, Tan J, Zang H, Wang T, Li Y, Cui S. Effects of septal deviation on the airflow characteristics: using computational fluid dynamics models. Acta Otolaryngol. 2012;132(3):290-8.

26. Chen XB, Lee HP, Chong VF, Wang de Y. Assessments of nasal bone fracture effects on nasal airflow: A computational fluid dynamics study. Am J Rhinol Allergy. 2011;25:e39-43.

27. Bailie N, Hanna B, Watterson J, Gallagher G. A model of airflow in the nasal cavities: Implications for nasal air conditioning and epistaxis. Am J Rhinol Allergy. 2009;23:244-9.

28. Tezel E, Durmuş FN. A new instrument for achieving a natural nasofrontal angle. J Plast Reconstr Aesthet Surg. 2009;62:e617-9.

29. Uzun A, Akbas H, Bilgic S, Emirzeoglu M, Bostanci O, Sahin B, et al. The average values of the nasal anthropometric measurements in 108 young Turkish males. Auris Nasus Larynx. 2006;33:31-5.

30. Uzun A, Ozdemir F. Morphometric analysis of nasal shapes and angles in young adults. Braz $J$ Otorhinolaryngol. 2014;80:397-402.

31. Janis JE, Rohrich RJ. Rhinoplasty. In: Thorne C, Beasley R, Aston S, Bartlett S, Gurtner G, editors. Grabb and Smith's Plastic Surgery. Philadelphia: Lippincott Williams and Wilkins; 2007:517-32.

32. Flint PW, Haughey BH, Lund VJ, Niparko JK, Richardson MA, Robbins KT, Thomas R. Cummings Otolaryngology: Head \& Neck surgery, 5th edn. St Louis (MO): Mosby Elsevier;2011; p679.

33. Monjas-Cánovas I, García-Garrigós E, Arenas-Jiménez JJ, Abarca-Olivas J, Sánchez-Del Campo F, Gras-Albert JR. Radiological anatomy of the ethmoidal arteries: CT cadaver study. Acta Otorhinolaringologica (English Edition). 2011:62;367-74.

34. Greco MG, Mattioli F, Alberici MP, Presutti L. Recurrent Massive Epistaxis from an Anomalous Posterior Ethmoid Artery. Case Rep Otolaryngol 2016; 2016: 8504348. 